\title{
Reading and Writing Activities on Instagram
}

\section{Kevin Thomas \\ Asia University}

\section{Reference Data:}

Thomas, K. (2020). Reading and writing activities on Instagram. In P. Clements, A. Krause, \& R. Gentry (Eds.), Teacher efficiency, learner agency. Tokyo: JALT. https://doi.org/10.37546/JALTPCP2019-54

In teaching a university course designed to improve English learners' spoken and written communication, I noticed a gap between coursebook reading and writing activities and students' communication, I
$\mathrm{L} 1$ practices. This led to the conclusion that coursebook activities should be supplemented to improve learners' motivation to read and write. An investigation into using social media in the classroom (Thomas \& Park, 2020) identified Instagram as a potentially suitable platform for such activities. ELT researchers have supported classroom use of Instagram, claiming its use had benefits for language learning, grammatical and lexical accuracy, and motivation (Al-Ali, 2014; Handayani, 2016; Listiani, 2016). This paper is a report on two experiments that were carried out to investigate these claims. Results showed no improvement in vocabulary memorization or grammatical and lexical accuracy. However, students were motivated by Instagram and felt it was a useful language-learning tool. In addition, a correlation was found between using the platform and engaging in activities.

大学における口頭·書面によるコミユニケーション向上のコースにて、コースブックのリーデイングとライテイングのアクティ ビテイと学習者の第一語による実生活での読み書きの活動に差異があることに着目したっこれにより、コースブックのアクテ イビテイは読み書きの学習意欲向上のために補填されるべきであるという結論に達した。このようなアクライビテイのための インスタグラム使用の有用性が示されており(Thomas \& Park, 2020)、文法·語军の正確さの習得と学翟意欲の向上に有益で あるとELT研究者達に支持されている(Al-Ali, 2014; Handayani, 2016; Listiani, 2016)。乙れらの主張を調查するため本研究で はニつの実験学行つた。結果は語魚の暗記と文法·語彙の正確さの習得について何ら向上を示さなかったが、学習者はイン スタグラムは学習意欲をを起とし、役に立つ学習ツールレであると感した。さらにインスタグラムを使用することとアクテイビティ に興味を惹かれるということに相関関係が見受けられた teach a Japanese university course designed to improve English learners' spoken - and written communication. Lessons are taught for 45 minutes, four times a week. The course is focused on spoken communication, but writing and reading for communication are also taught. The set coursebook is a commercially available preintermediate textbook that includes the four skills. Previous research (Thomas, 2017) identified a gap between coursebook reading and writing activities in L2 and learners' L1 reading and writing practices. The research, a survey of 63 learners, showed that the majority of L1 reading and writing for communication was conducted via social media on smartphones. These findings, along with other authors' arguments that L1 literacy practices should inform L2 classroom literacy activities (Moll, Amanti, Neff \& Gonzalez, 1992), led to the recommendation that the coursebook be supplemented with more authentic smartphone-accessed social-media-based reading and writing activities. It was suggested that such activities would make student writing and reading more genuinely communicative, would increase motivation, and would potentially improve the language ability of learners (Thomas, 2017).

More detailed follow-up research (Thomas \& Park, 2020) investigated 288 learners' social media practices. The most popular social media platform among students was Instagram. The majority of learners used it to communicate with peers and were aware of and able to use its features. Inspired by literature that has shown the benefits of using Instagram as a teaching and learning tool (Handyani, 2016; Khalitova \& Gimaletdinova, 2016), we designed a pilot Instagram reading and writing activity, adapted from the coursebook, in order to gauge if learners found Instagram-based activities enjoyable and motivating and to determine whether it was a potentially effective learning tool. Student feedback was overwhelmingly positive (Thomas \& Park, 2020).

The purpose of the study detailed in this paper was primarily to investigate whether using Instagram as a platform for reading and writing activities can demonstrably improve students' language ability. The secondary objective was to discover whether the students believe Instagram to be a useful and motivating language tool. In order to 
inform the study's experimental design and research questions, I carried out a literature review to answer the following questions:

1. How can the features of Instagram be used by ELT practitioners?

2. How does the use of such features in the classroom fit into English language learning theory?

3. How has Instagram been used by researchers to attempt to improve students' reading and writing abilities?

\section{Instagram Features and the ELT Classroom}

ELT researchers have claimed that the features of Instagram accessed by smartphones can be utilized in teaching English. Instagram is primarily a social media application for sharing photographs. This feature has been seen as useful for presenting vocabulary (Handayani, Cahyono, \& Widiati, 2018). Constantinescu (2007) held that vocabulary is key to proficient reading and writing and argued that learners prefer vocabulary to be taught alongside visuals rather than with purely written explanations. Social networking sites such as Instagram provide a suitable medium for presenting vocabulary. Alzahrani (2015) provided support for this, suggesting that her use of mobile flashcards showed students had "positive attitudes towards using mobile technology in learning new vocabularies" (p. 108). Zárate and Cisterna (2017) also noted the positive implications of this feature, finding that the posting of pictures by teachers and peers motivated learners to memorize items.

Instagram allows users to post comments alongside their images. This feature can be used to have learners create descriptive texts. Al-Ali (2014) illustrated how Instagram can be used to create such texts on various personal topics. According to Akhiar, Mydin, and Kasuma (2017), descriptive texts "require writers' creativity to employ suitable adjectives in their descriptions of people, events, and things for impactful writing" (p. 53). Having a personal picture to support a text is seen as motivating learners to be precise in their descriptions. Describing a personal picture is likely a more authentic activity for a learner than describing a general image presented in a coursebook.

Instagram also allows users to comment on the images and text of others. This feature permits multiple users to comment on a single photo, which can enable learners to participate in group written activities (Zárate \& Cisterna, 2017). Suryantari and Piriyana (2018) described how Instagram allows students to "exchange views and opinions on various topics" (p. 300), suggesting that through this exchange, students can collaborate via writing, which naturally involves reading what others have written.

\section{Instagram and Communication Theory}

The potential of Instagram features to promote language learning and increase motivation in the ELT classroom is supported by communication theory.

The main purposes of daily communication including written texts have been described as either transactional or interactional (Meisani, Chofiyya, and Handayani, 2016). Transactional communication involves speakers or writers taking turns in order to achieve a goal, such as buying something from a seller. On the other hand, interactional communication refers to an exchange of ideas, information, and rules in order to create or maintain relationships. Meisani et al. (2016) suggested that both forms of communication require the communicators to be aware of turn taking, statusrelated conventions, and social pragmatics. In addition, both types happen verbally and nonverbally. Verbal communication refers to "communication which is delivered by the speaker to hearer in written and spoken language to express ideas, feelings, emotions and desires" (p. 93), whereas nonverbal communication refers to all that is communicated without words, for example through gestures, body language, or the use of emoji in written digital text. Instagram features allow both verbal and nonverbal written transactional and interactional communication. They allow speakers to successfully negotiate through problems and express themselves verbally in written text and nonverbally with photographs and emoji. For example, a user can transactionally communicate with a commercial business on Instagram, arranging to buy goods or ask about services, or a user could communicate interactionally by creating content or interacting with that of others to establish or maintain relationships.

Communication theory suggests that social networking services such as Instagram can provide a platform on which students can communicate, negotiate meaning, and improve language skills. Norizan, Murad, and Zulkifli (2013) used Vygotsky's influential social learning theory to illustrate how interacting through Instagram can create learning opportunities and facilitate language development. They quoted Vygotsky as arguing that learning takes place when there is "collaborative learning and learner-learner meaningful interaction" (p. 187). The commenting functions of Instagram provide this collaborative and interactional space in which learning can take place.

Zárate and Cisterna (2017) suggested that interacting with peers and other L2 language learners can improve writing skills because the communicative platform provided by Instagram allows users "to construct their own communication nets and not only receive information as a passive audience, ... [and] learning power availability is greatly boosted" (p. 529). As the audience of users who actively follow each other is not 
seen as passive, Zárate and Cisterna argued it encourages learners to create better and more meaningful writing.

Participating in the social space created by Instagram has also been seen to benefit reading ability. Morshidi, Embi, and Hashim (2019) argued that the opportunity to interact with a text increased reader interest, resulting in greater motivation to read and improve reading skills. Tama (2018) argued that Instagram is a platform that can provide such motivational interaction with written texts. Motivation to interact is increased because texts are often created by peers, whether they are fellow Instagram users or friends and acquaintances.

\section{Instagram and Reading and Writing}

ELT researchers have attempted to utilize the features of Instagram to make reading and writing lessons richer in opportunities for language learning and more motivating for learners. Researchers have claimed evidence of success on the bases of both learner opinion and language analysis.

Akhiar et al. (2017) asked 101 students to write a descriptive essay about a possession that was important to them and to support their description with pictures. To measure perceptions on whether using Instagram had improved students' writing, they created a questionnaire including qualitative and quantitative questions. According to their findings, learners held "positive perceptions and views towards using Instagram in improving their writing skills" (p. 48). The authors concluded that Instagram-based activities were perceived by students to have improved their language because having an audience made them focus more on grammatical and lexical accuracy.

In separate research using learner opinion as indication of the utility of classroom use of Instagram, Morshidi et al. (2019) found that learners saw classroom use of Instagram as having positive effects on their reading behavior. Thirty learners were given a series of reading activities on Instagram, followed by a questionnaire. Results showed that reading texts accompanied by photos on Instagram encouraged engagement with the written text and motivated learners to participate in activities.

Although this research shows evidence of belief in the effectiveness of Instagram in the teaching of reading and writing, it provides no evidence about how this happened, what areas of language improved, or if language improved at all. Other researchers have attempted to analyze whether using Instagram and other social media platforms can help learners develop grammatical and linguistic accuracy. In their study of using Facebook for descriptive writing, Norizan et al. (2013) claimed to have found evidence that social- media-based activities promote greater student focus on accuracy and encourage learners to put more effort into understanding texts. They came to these conclusions through a quantitative analysis of how learners support each other's writing through the use of social networking sites.

Indonesian researchers Soviyah and Etikaningsih (2018) similarly used Instagram to have students write a descriptive text supported by pictures. They created an experimen in which the same four writing lessons were completed by different groups of students either on Instagram or using pen and paper. The lesson series research included a pretest and posttest. Using a descriptive analysis, they claimed their research showed that writers using Instagram images produced higher quality descriptive texts.

Research providing evidence of the potential of Instagram to improve learners' language ability in a similar context to my own is limited. Research has gauged success based only on learner opinion, used a different social media platform, or been done outside of Japan.

\section{The Research}

The experiments outlined were designed to investigate the following research questions:

RQ1. Does presenting vocabulary through Instagram aid memorisation?

RQ2. Does using Instagram as a platform for writing activities improve learners' grammatical and lexical accuracy?

RQ3. Does using Instagram as a platform for writing activities result in learners producing more text?

RQ4. Do learners find using Instagram for writing activities motivating?

RQ5. Is Instagram perceived to be a useful classroom activity by the learners and teachers?

Two experiments were conducted. For both experiments, activities were created based on those in the coursebook. The first experiment was designed to investigate RQ1 and was followed by a survey to investigate RQ4 and RQ5.

I teach four classes of a similar level, using the same coursebook-a pre-intermediate four-skills English course with a focus on communication. The majority of learners are Japanese, aged between 18 and 19 years. Three of the classes have an overseas student either from China or Vietnam, each of whom is 22 years old. The classes are roughly even in the numbers of males and females. It is compulsory for students to take English classes during their 1st year, but there is little opportunity to study English in the following 
years. The university is private and has an extensive study abroad program; however, only three of the students involved in this study will join this during their 2nd year.

\section{Experiment One}

For the experiment, four groups of learners (two Instagram groups of 15 and 12 learners and two paper-based groups of 14 and 13 learners) were given a set of eight vocabulary items as an activity that was part of a larger lesson. Activities were carried out once a week over 4 weeks, making 32 vocabulary items in total. Informed consent and institutional clearance were given for all data to be used in this paper.

Two groups were given the vocabulary items on paper accompanied by pictures; the other two groups were presented the items via Instagram. All four vocabulary sets were on the theme of shopping: Two sets were nouns related to food and household goods, and two sets were adjectives related to technology and clothing. There is strong evidence that presenting meaning-related words together can aid learning (Papathanasiou, 2009). The noun activities involved writing the names of objects before being given answers. The adjective activities were matching activities: Students matched provided answers to pictures. In the paper-based activity group, students recorded answers and then called them out before being given the correct answer. In the Instagram activity, answers were given as comments on the teachers' picture posts, and the correct answer was input as an additional comment by the teacher (see Appendix A). All activities for the paper-based and Instagram groups were part of a larger lesson, preceded by a warm-up activity and followed by a practice activity. All students were told they would be given a paper-based test in Week 5 , which consisted of the same matching and labelling activities presented in the lessons.

For the Instagram group, a preceding lesson was given in which students created a new user name or new account on Instagram. Students then "followed" each other so they would be alerted to any posts made by their peers. Security settings were set to private so only class members could see posts. A practice activity was done in which students posted a picture and made comments to accustom them to the technology.

In order to assess how successful the intervention was, the answers from the Week 5 test were tallied. Following the experiment, Instagram students were given a Likert-style questionnaire to assess whether they perceived using Instagram to be motivational and useful as a classroom tool (see Appendix B).

Concerning RQ1, whether using Instagram aided lexical memorization, the results were negative. The results from the test were graded according to the university's grading system:four pass grades from S (90-100\%) to C (60-70\%); anything under $60 \%$ is a D and a fail. The institution grading system was used in order to make the differences between groups easier to visualize. Results for all levels of pass and fail were similar (see Table 1). For example, the Instagram groups had four $\mathrm{S}$ grade passes compared with three for the paper-based groups. Concerning failures, the Instagram groups had 11 compared with nine for the paper-based groups. It could be said the paper-based groups did slightly better at lower pass levels (B and C: 13 vs. 9) and Instagram groups at higher pass levels (A and S: 7 vs. 5), but the numbers are negligible.

Table 1. Grades of All Four Experimental Groups ( $N=54)$

\begin{tabular}{lcccc} 
Grade & Instagram 1 & Instagram 2 & Paper group 1 & Paper group 2 \\
\hline Fail & 8 & 3 & 5 & 4 \\
C & 2 & 1 & 4 & 1 \\
B & 3 & 3 & 3 & 5 \\
A & 0 & 3 & 2 & 0 \\
S & 2 & 2 & 0 & 3 \\
\hline
\end{tabular}

In the survey carried out to investigate RQ4 and RQ5, the Instagram groups' feedback on the Likert-style questionnaire was positive (see Appendix B). The majority found the lessons enjoyable (Q.1), motivating (Q.3), and effective (Q.5). To each question, 26 out of 27 answered strongly agree or agree.

As the teacher, $\mathrm{I}$ also considered the classes a success based on a number of criteria. Concerning communication, in follow-up activities students interacted on a class-wide level, that is, with students they did not usually sit beside or interact with. In addition, students who usually did not speak in class initiated conversations and participated more frequently. From a teacher's perspective, less preparation time was a benefit, as was the permanent nature of digital materials. There were also no learner or teacher technical issues.

\section{Experiment Two}

A second experiment was created to investigate RQ2 and RQ3. Three activities were created. In two activities, learners were asked to write a descriptive text after seeing 
a model answer provided by the teacher. The first activity involved writing about the learners' hometown; the second was about a famous person. As in the previous experiment, two groups were given the task via Instagram and two were asked to complete it with pen and paper. A 78-word model written by the teacher was given for both texts. The Instagram-based model text was presented digitally alongside a picture; the paper-based groups' model was written on the board. Students for both groups were given 15 minutes to create a text and include a picture in the case of Instagram (see Appendix C). Pictures were either ones students had taken themselves or found on the Internet. Although this might have given students less time to write, the personalization of texts provided by such pictures has been identified as one of the motivational features of Instagram (Listiani, 2016).

After the texts were produced, the paper-based learners were instructed to attach their papers to the classroom walls. The Instagram group could view peers' texts through their own feed. For the following 10 minutes, students read each other's texts either on Instagram or by circling the classroom. A further 10 minutes was then given for students to ask questions about each other's towns or famous people either via Instagram comments or on pieces of paper (see Appendix C). During the final 10 minutes, students produced written answers to the questions. The teacher provided grammatical, lexical, and prosodic corrections for both answers and questions either via Instagram comment or by verbally communicating errors to students and having them write them in their notebooks.

In order to analyze students' descriptive writing, a simple percentage analysis was used, in which two sets of writing can be quantitatively compared for differences (see Zárate \& Cisterna, 2017). This can include comparing grammatical inaccuracies, length of text, and the frequency of interactional occurrences (Norizan et al., 2013).

The descriptive texts for both hometown and famous person were analyzed first based on the number of words. The total word counts for the Instagram and non-Instagram group were tallied and an average was determined. The average word count was 42 for the Instagram group and 52 for the non-Instagram group. A similar analysis was done for grammatical and lexical mistakes made. The Instagram group averaged 2.4 mistakes compared with 2.3 for the non-Instagram groups. The number of comments and questions from other students per text when tallied showed an average 5.8 for the Instagram group compared with 2.4 for the paper-based groups.

For the third activity, learners were split into the same Instagram and paper-based groups as in previous activities. Learners were asked to make plans to meet with three other students for a social purpose. This activity followed a coursebook lesson on functional language for making arrangements. The Instagram groups were asked to upload three separate photos, representing Friday, Saturday, and Sunday respectively. Most students took a screenshot of their smartphone calendar, highlighting the particular days. They were then given 20 minutes and were able to approach anyone with an invitation. They had to make three separate plans with three different students, responding positively to any invitations when they had free time and responding negatively if they had already made a plan with another student. If the invitee was busy, they would both need to approach someone else (see Appendix D). The paper-based students were put into groups of three or four and given nine (when in groups of three) or twelve (when in groups of four) sheets of paper. They had to write the name of each day on as many pieces of paper as they had partners. For example, if a learner had three partners, they wrote Friday on three pieces of paper, Saturday on three, and Sunday on three. The paper-based group were also given 20 minutes to make their plans. Without speaking, they passed their papers to their partners, asking questions in writing and giving written responses, responding positively when they had free time and negatively if they were busy. Both Instagram and paper-based groups orally reported to the class about their plans after the activity.

In the collaborative communicative texts, the average number of interactional sentences in the conversation was eight for both groups; the Instagram groups' conversations also featured emoji. The Instagram participants attempted to initiate written conversations with more peers, as there was a greater pool of people to approach.

\section{Discussion}

The answer to RQ1, RQ2, and RQ3, whether conducting activities via Instagram improved student language ability, was negative. The results of the first experiment showed no connection between vocabulary acquisition and whether the vocabulary was presented via Instagram. However, the experimental time period was short. Perhaps over a longer period a difference would have become discernible. As noted previously, presenting vocabulary digitally allows a permanent record with less chance of learners losing the vocabulary. The benefits of this permanence may be seen over time. In the second experiment, students produced less text digitally compared with on paper when given the same model text. Within these texts, the number of grammatical mistakes was roughly the same.

However, conducting activities via Instagram was found to be useful and motivating (RQ4 and RQ5), according to both student opinion and my own observations. The most positive effect of the intervention concerns students' engagement with texts. The 
Instagram groups made over twice as many comments on each other's pictures posted in the second experiment, which necessitated a corresponding number of replies. This showed the use of Instagram inspired more interaction between students. Also, although the number of lines of conversation was the same in the collaborative communication lesson, Instagram group learners attempted to initiate more conversations, producing more language. It is important to note, however, that the experimental design provided Instagram users a greater pool of peers to approach. For the sake of a fair comparison, it may have been better to have restricted the number of approachable peers for both groups equally. However, I felt that would have been artificially constraining the Instagram users and would have failed to recognise a positive aspect of the technology for classroom teaching. As I teach in a small classroom, having students physically move around and approach each other is logistically difficult; using Instagram allows students to do something they couldn't do with ease physically.

The results of this experiment suggest that when using Instagram in class, its utility may be in encouraging students to interact in writing more, producing more interactional communicative language and allowing them to communicate with more people than they would be able to if confined by the classroom's physical limitations. Although the intervention revealed no effect in acquisition, accuracy, or amount of descriptive language production, it encouraged the production of meaningful interactive language, which emerged from the increased personalization made possible by the use of learner pictures. As a main goal of the course in question is improved communication, using Instagram in class would seem to have utility, although not as a tool for encouraging increased vocabulary memorization and lexical and grammatical accuracy, which was under primary investigation in this study.

\section{Conclusion}

Social media platforms are useful classroom tools. Writers have promoted different ways in which they could facilitate language learning (Suryantari \& Priyana, 2018; Soviyah \& Etikaningsih, 2018; Zárate \& Cisterna, 2017). Instagram functions and popularity make it particularly suitable for classroom use. The results of the study suggest that the advantage of Instagram is its motivating role in encouraging learners to interact, collaborate, and more readily produce written communication. In communicationbased courses, Instagram could help bridge the gap between coursebooks and students' real-life use of language. Although Instagram use in class did not improve vocabulary acquisition and grammatical accuracy, it was seen as a motivating and useful use of class time by both teacher and learners. Using Instagram as a supplement to coursebooks in collaborative activities in class is worthy of consideration by those teaching English for communication. Further research into different types of interactional communication activities that could be done via Instagram could be useful in guiding teachers on how to integrate it into existing curricula.

\section{Bio Data}

Kevin Thomas has been an English teacher since 2002 and has worked at universities in the U.K. and Japan. He is currently a visiting faculty member at Asia University, Japan. His interests are preparing Japanese students for study abroad and creating more authentic written communication activities in classes. Kevin has presented his research on the potential of Instagram as a learning tool in Vietnam, Malaysia, and Japan.

\section{References}

Akhiar, A., Mydin, Al-A., \& Kasuma, S. A. A. (2017). Student's perceptions and attitudes towards the use of Instagram in English language writing. Malaysian Journal of Learning and Instruction (MJLI), Special Issue on Graduate Students Research on Education, 47-72. Retrieved from http:// mjli.uum.edu.my

Al-Ali, S. (2014). Embracing the selfie craze: Exploring the possible use of Instagram as a language learning tool. Issues and Trends in Educational Technology, 2(2), 1-16. Retrieved from https:// journals.uair.arizona.edu/index.php/itet/index

Alzahrani, H. (2015). Examining the effectiveness of utilizing mobile technology in vocabulary development for language learners. Arab World English Journal, 6(3), 108-199. https://doi. org/10.24093/awej/vol6no3.7

Constantinescu, A. I. (2007). Using technology to assist in vocabulary acquisition and reading comprehension. The Internet TESL Journal, 13(2). Retrieved from http://iteslj.org/Articles/ Constantinescu-Vocabulary.html

Handayani, F. (2016). Instagram as a teaching tool? Really? In Proceedings of the fourth international seminar on English language and teaching (pp. 320-327). Retrieved from http://ejournal.unp.ac.id/

Handayani, A. D., Cahyono, B. Y., \& Widiati, U. (2018) The use of Instagram in the teaching of EFL writing: Effect on writing ability and students' perceptions. Studies in English Language Teaching, 6(2), 112-126. https://doi.org/10.22158/selt.v6n2p112

Khalitova, L. \& Gimaletdinova, G. (2016). Mobile technologies in teaching English as a foreign language in higher education: A case study of using mobile application Instagram. In L. Gomez Chova, A. Lopez Martinez, \& I. Candel Torres (Eds.), ICERI2016 Proceedings (pp. 6155-6161). Seville, Spain. https://doi.org/10.21125/iceri.2016.0395 
Listiani, G. (2016). The effectiveness of Instagram writing compared to teacher centered writing to teach recount text to students with high and low motivation (The case of eight grade students in SMP Kesatrian 1 Semarang in the academic year of 2015/2016). ELT Forum: Journal of English Language Teaching, 5(11), 1-8. https://doi.org/10.15294/elt.v5i1.9875

Meisani, S. R., Chofiyya, N. N., \& Handayani, R. (2016). Captions writing in Instagram Understanding the meaning and the communicative function in learning language. Jambi-English Language Teaching Journal, 1(2), 90-97. Retrieved from https://online-journal.unja.ac.id/jelt/ article/view/3437

Moll, L. C., Amanti, C., Neff, D., \& Gonzalez, N. (1992) Funds of knowledge for teaching: Using a qualitative approach to connect homes and classrooms, Theory Into Practice, 31(2), 132-141. https://doi.org/10.1080/00405849209543534

Morshidi, A., Embi, M. A., \& Hashim, H. (2019). Instagram application: An active tool in cultivating reading behavior. Journal of Information System and Technology Management, 4(11), 95-106. Retrieved from http://www.jistm.com

Norizan, A. R., Murad, S., \& Zulkifli, A. (2013). Adopting social networking sites (SNSs) as interactive communities among English foreign language (EFL) learners in writing: Opportunities and challenges. English Language Teaching, 11(6), 187-198. https://doi. org/10.5539/elt.v6n11p187

Papathanasiou, E. (2009). An investigation of two ways of presenting vocabulary. ELT Journal, 64(4), 313-322. https://doi.org/10.1093/elt/ccp014

Soviyah, S., \& Etikaningsih, S. E. (2018). Instagram use to enhance ability in writing descriptive texts. Indonesian EFL Journal, 4(2), 32-38. https://doi.org/10.25134/ieflj.v4i2.1373

Suryantari, H., \& Priyana, J. (2018). Exploring ways of using Facebook and Instagram in teaching English. In W. Striełkowski, \& J. Cheng (Eds.), Proceedings of the International Conference of Communication Science Research (ICCSR 2018) (pp. 298-301). https://doi.org/10.2991/ iccsr-18.2018.66

Tama, G. K. (2018). Students' overview towards peer-correction activity on students-made advertisement uploaded in Instagram. In V. Novita, D. P. Saraswat, M. C. Wulandar, I. A. Dennaya, N. Widianingtas, A. C. Nugrehen, ... M. D. Andarupraja (Eds.), The 6th Undergraduate Conference on ELT, Linguistic and Literature (pp. 180-187). Snata Dharma University Press. ISBN: 978-602-5607-38-7

Thomas, K. (2017). L1 literacies and possible implications for the communicative language teacher. CELE Journal, 25, 99-120. Retrieved from https://asia-u.repo.nii.ac.jp

Thomas, K., \& Park, S. (2020). Integrating Instagram into the curriculum of a Japanese freshmen English communication course for reading and written activities. CELE Journal, 28, 93-116. Retrieved from https://asia-u.repo.nii.ac.jp
Zárate, P., \& Cisterna, C. (2017). Action research the use of Instagram as an interactive tool for developing the writing of short stories. European Journal of Education Studies, 2(8), 527-543. https://doi.org/10.5281/zenodo.1035497

Appendix A

Sample Instagram Activities

Instagram food vocabulary presentation

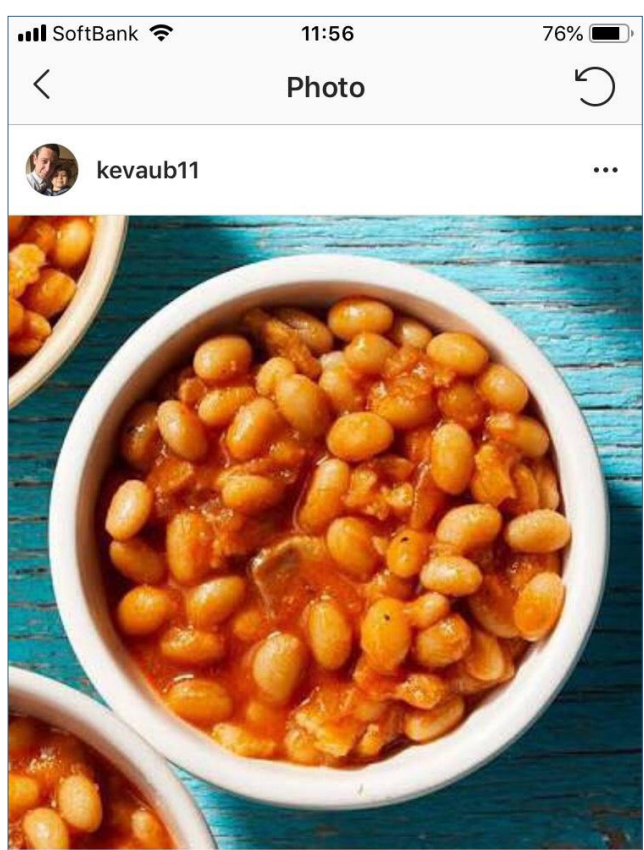

\section{$\bigcirc \bigcirc \nabla$}

vo mas a....... minestrone

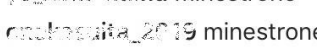
$1 \mathrm{H} Y 22$

$\widehat{\Omega}$ $\bigoplus$
曰

$\cdots$

(8)

$\begin{array}{lcc}\text {.II SoftBank } ₹ & 11: 56 & 76 \% \\ < & \text { Comments } & \end{array}$

6. ........ - minestron

iv Reply

f. Warahsuminestrone

Reply

2.

Iw Reply

an as atom Minestrone

1w Reply

A 3 minestrone

Reply

8. kevaub11 Baked beans

Reply

(2) s.s. $254 \pi \cdot 3$ minestron Reply

(7)

\section{$\nabla$}

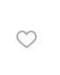

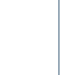

P

0

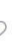

Add a comment as kevaub11. 


\section{Sample Paper-Based Lessons}

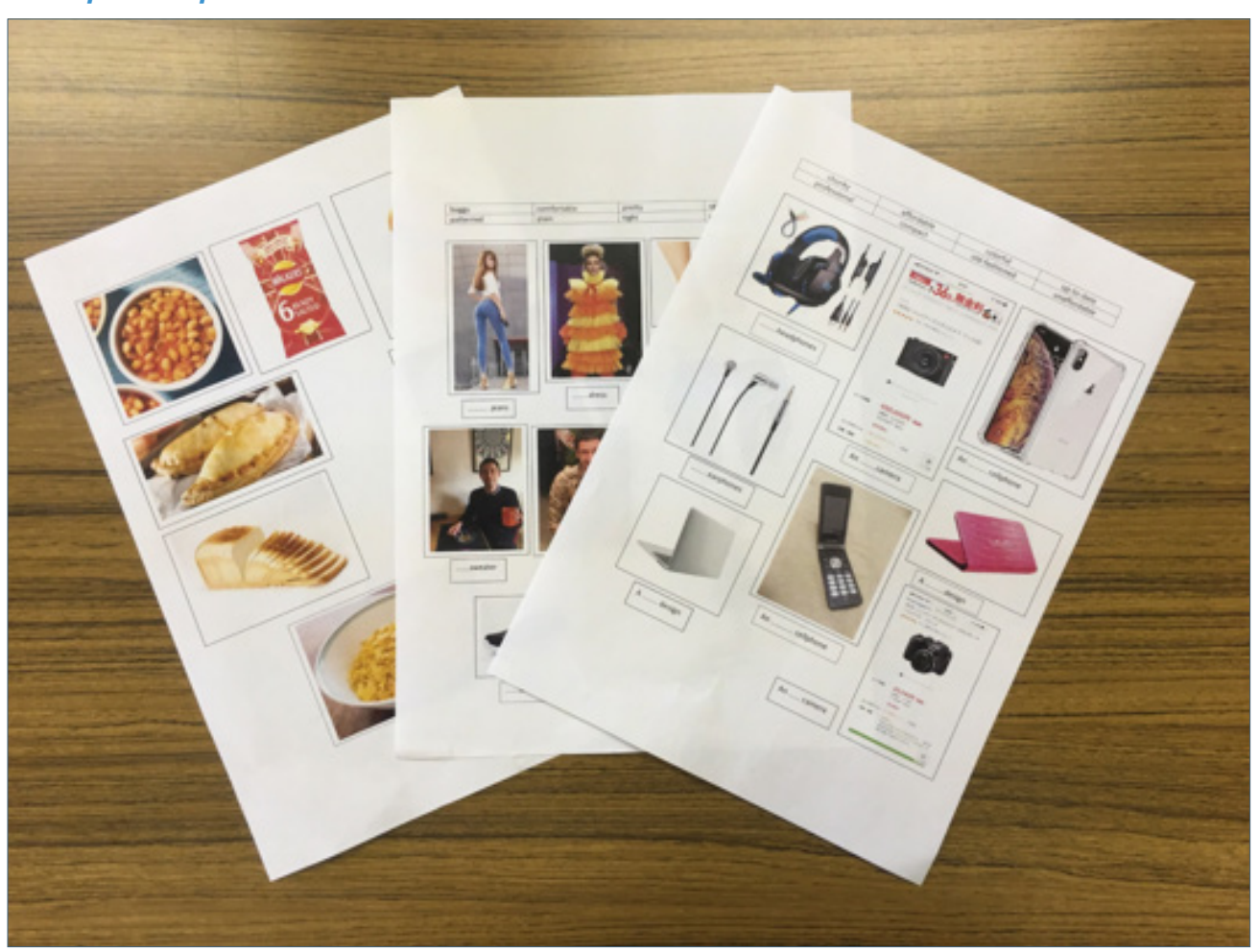

\section{Appendix B}

Instagram Questionnaire Results: Both Classes ( $n=27)$

\begin{tabular}{|c|c|c|c|c|c|}
\hline Statement & $\begin{array}{l}\text { Strongly } \\
\text { agree }\end{array}$ & Agree & $\begin{array}{l}\text { Neither } \\
\text { or } n / a\end{array}$ & Disagree & $\begin{array}{l}\text { Strongly } \\
\text { disagree }\end{array}$ \\
\hline $\begin{array}{l}\text { 1. I enjoyed the Instagram } \\
\text { lesson. }\end{array}$ & 19 & 7 & 0 & 1 & 0 \\
\hline 2. I learnt more than usual. & 16 & 12 & 1 & 0 & 0 \\
\hline $\begin{array}{l}\text { 3. Using Instagram made me } \\
\text { want to use English more. }\end{array}$ & 15 & 11 & 0 & 1 & 0 \\
\hline $\begin{array}{l}\text { 4. I would like to use Instagram } \\
\text { once a week in future classes. }\end{array}$ & 16 & 7 & 3 & 1 & 0 \\
\hline $\begin{array}{l}\text { 5. I think using Instagram } \\
\text { helped me to remember the } \\
\text { words in the test. }\end{array}$ & 16 & 10 & 1 & 0 & 0 \\
\hline $\begin{array}{l}\text { 6. I found the grammar and } \\
\text { spelling corrections given in } \\
\text { replies helpful. }\end{array}$ & 21 & 4 & 1 & 1 & 0 \\
\hline $\begin{array}{l}\text { 7. I thought the Instagram } \\
\text { lessons were a useful use of class } \\
\text { time. }\end{array}$ & 21 & 3 & 1 & 2 & 0 \\
\hline
\end{tabular}

Paper-based activities 
Appendix C

A Selection of Descriptive Texts Produced by Students via Instagram and Paper Based

\begin{tabular}{|c|c|c|}
\hline .tll SoftBank $\%$ & 12:01 & $417 \%$ \\
\hline (0) & Instagram & 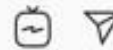 \\
\hline
\end{tabular}

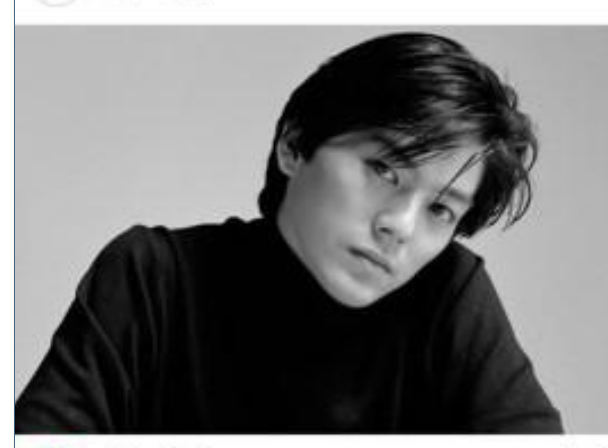

$\bigcirc \vee$

W

1 like

1965 and liedmire Ozaki Yutaka. He was born in his debut in 1983. He sang the song "I LOVE YOU". This song is very famous. He was cool but he was cheerful in private. He was loved by fans even after

View all 12 comments

LOVE YOU"?
Do you often listen to the song "I

Which of him song do you tike?

ค $\mathrm{Q} \oplus \mathrm{b}$
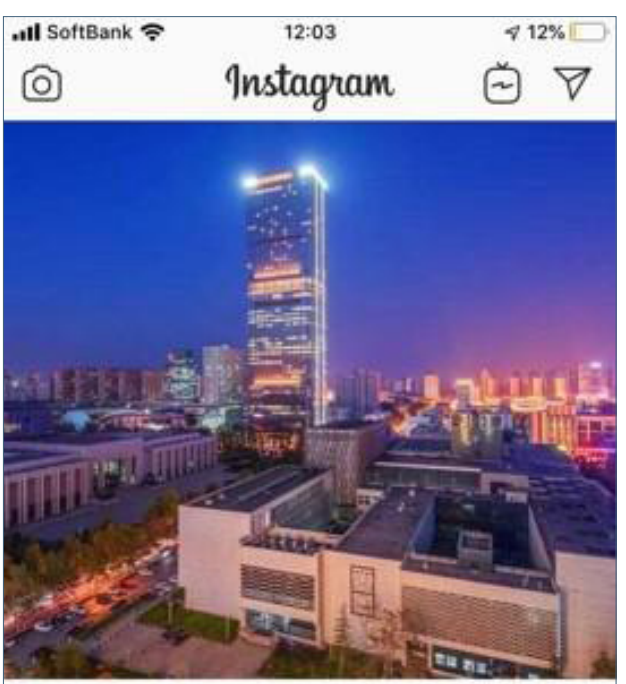

$\odot \bigcirc \nabla$

......

W

Hiked by 2 in and 1 other

"'My hometown is called Shijiazhuang.It's in the north of the China.The weather in summer is so hot,and in winter is so cold. Shijiazhuang has a big

th Shiliazhung and Nage it to go to Bejing only In last picture is the oldest stone arch bridge in the world called Zhaozhou bridge.

- $\rightarrow \oplus ?$

\section{Facsimile of students' writing (reproduced for clarity)}

I admire Whitney Houston.

She was born in 1963 in the USA and died in 2012 in the USA.

She is one of the bestselling singers in the world.

There are many different genres of songs to sing,

including $\mathrm{R} \& \mathrm{~B}$ and gospel.

She has also appeared in movies.

She married a singer in 1992 and had a baby. 


\section{Appendix D}

Examples of Interactional Texts Produced by Students via Instagram and Paper Based

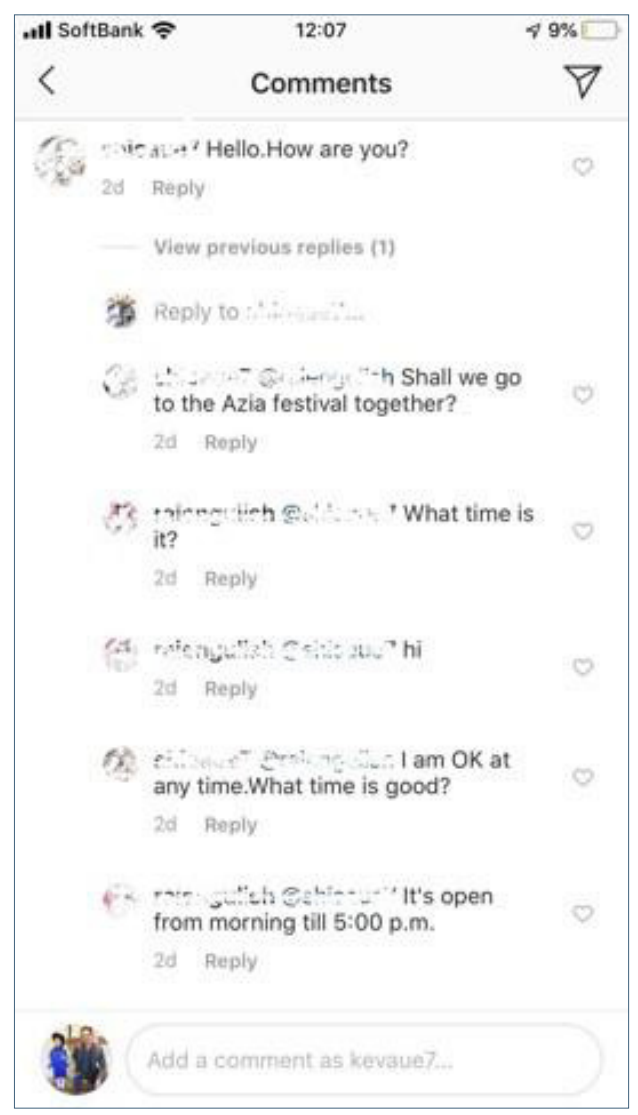

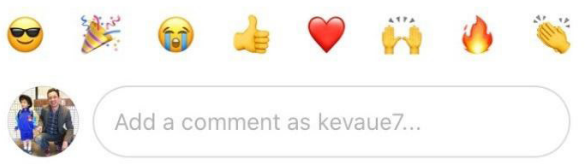

\section{Facsimile of students' writing (reproduced for clarity)}

\section{Conversation 1}

Student A - Let's go to the Ramen festival on Monday

Student B - Sounds great!

Student A - What's time is good for you?

Student B - It's 11 o'clock

Student A - That's good for me, where shall we meet?

Student B - Setagaya station

\section{Conversation 2}

Student A - How long does it take to arrive from here?

Student B - About one hour

Student A - Do you have any other festival?

Student B - No, only one festival. 